\title{
POTENSI KONFLIK BERPENGARU TERHADAP PENINGKATAN EKONOMI MASYARAKAT KOTA GORONTALO
}

\author{
Hasanuddin $^{1 *}$, Ismail Suardi Wekke ${ }^{2}$, Mulyana Machmud ${ }^{3}$, Ibnu Hajar Sainuddin ${ }^{4}$ \\ ${ }^{1}$ Universitas Gorontalo, Indonesia \\ ${ }^{2}$ Institut Agama Islam Negeri (IAIN) Sorong, Indonesia \\ The Jusuf Kalla Research Center for Bugis Makassar Cultural Studies, \\ Universitas Muslim Indonesia \\ ${ }^{3}$ STIE AMSIR Parepare, Indonesia \\ ${ }^{4}$ STAI DDI Kota Makassar, Indonesiaq \\ *Korespondensi : achankbagu.bone@gmail.com
}

\begin{abstract}
The method used is a participatory multidimensional approach with the research location of Gorontalo City. This research uses literature study by searching through print media and internet links. The primary data in this study was through interviews with traditional and cultural leaders, religious leaders as well as secondary data from local government agencies and other related institutions (Polri, NGO, CSO, Media). Types of data and sources of conflict include three-year data $(2010$ - 2012). This research shows that in 2010 the type of conflict between community members and the government was very dominant with the percentage reaching 50\%, the next is the potential for natural resourceleconomic conflict with a percentage of $26 \%$, the potential for communal conflict at $18 \%$, while for the potential for political conflict, Sara and relations industry, only 2\% each. In 2011 the type of communal conflict reached 57\%, then the potential for political conflict was $22 \%$, the potential for conflict between residents and the apparatus was $10 \%$ and the rest the potential for Sara conflict and natural resourceleconomic conflict were $6 \%$ and 5\%, respectively. The potential for conflict affects the potential for improving the community's economy and also has an impact on social conflict, so a regional autonomy policy is needed to prevent potential conflicts by optimizing economic achievements and their implementation.
\end{abstract}

Key words : Conflict, Economic, Tribe, Social.

\begin{abstract}
ABSTRAK
Metode yang digunakan adalah pendekatan multidimensi partisipatif dengan lokasi penelitian Kota Gorontalo. Pada penelitian ini menggunakan studi literatur dengan penelusuran melalui media cetak serta link internet. Data primer dalam penelitian ini melalui interview dengan tokoh adat dan budaya, tokoh agama serta data sekunder dari instansi pemerintah daerah dan terkait lainnya (Polri, LSM, CSO, Media). Jenis data dan sumber konflik meliputi data tiga tahun (2010 - 2012). Peneitian ini menunjukkan bahwa tahun 2010 jenis konflik antara warga masyarakat dengan pemerintah sangat dominan terjadi dengan persentasi mencapai $50 \%$, berikutnya adalah potensi konflik SDA/ Ekonomi dengan persentasi 26\%, potensi konflik komunal sebesar 18\%, sedangkan untuk potensi konflik politik, Sara dan hubungan industri, masing-masing hanya sebesar 2\% saja. Pada tahun 2011 jenis konflik komunal mencapai 57\%, selanjutnya potensi
\end{abstract}


konflik politik sebesar $22 \%$, potensi konflik antar warga dan aparat sebesar $10 \%$ dan sisanya potensi konflik Sara dan konflik SDA/ekonomi masing-masing sebesar 6\% dan 5\%. Potensi konflik berpengaruh terhadap potensi peningkatan ekonomi masyarakat dan juga berdampak pada konflik sosial sehingga diperlukan kebijakan otonomi daerah untuk mencegah terjadinya potensi konflik dengan mengoptimalkan pencapaian ekonomi dan implementasinya.

Kata Kunci : Konflik, Ekonomi, Suku, Sosial.

\section{PENDAHULUAN}

Ketimpangan pembangunan antara Kawasan Barat dan Timur Indonesia merupakan sebagian fakta bahwa ketidakadilan dan kesenjangan social ekonomi masih menjadi persoalan. Pada aspek lainnya permasalahan munculnya ketidak terkendalinya dinamika kehidupan politik dalam transisi demokrasi tatanan dunia yang makin terbuka mengakibatkan semakin cepatnya dinamika sosial yang berkembang, termasuk faktor intervensi yang dilakukan oleh pihak asing.

Kondisi ini menempatkan Indonesia sebagai salah satu negara yang rawan terhadap konflik, terutama konflik yang bersifat horisontal. Konflik tersebut, terbukti telah mengakibatkan hilangnya rasa aman dan nyaman pada masyarakat, timbulnya rasa takut bagi masyarakat, kerusakan lingkungan, kerugian harta benda, adanya korban jiwa dan trauma sacara psikologis seperti dendam, benci, dan antipati, sehingga menghambat terwujudnya kesejahteraan umum di masyarakat. Negara berkewajiban melindungi segenap bangsa Indonesia serta mewujudkan ketertiban umum dan perdamain Dunia.

Ciri utama masyarakat majemuk (plural society) menurut Furnifall dalam (Agus Sjafari 2017) adalah kehidupan masyarakatnya berkelompok-kelompok yang berdampingan secara fisik, tetapi mereka (secara essensi) terpisahkan oleh perbedaanperbedaan identitas sosial yang melekat pada diri mereka masing-masing serta tidak tergabungnya mereka dalam satu unit politik identitas tertentu. Sehinga masyarakat memiliki tanggung jawab secara fisik terhadap apa yang menjadi identitas mereka, walaupun adanya perbedaan kepentingan dalam struktur masyarakat.

Konflik dilatar belakangi oleh perbedaan ciri-ciri yang melekat pada individu dalam suatu interaksi soaial. Perbedaan-perbedaan tersebut dapat dikategorikan dalam beberapa bentuk, diantaranya menyangkut perbedaan fisik, 
kepandaian, pengetahuan, adat istiadat, keyakinan/agama, dan lain sebagainya. Konflik adalah sesuatu yang wajar, kapan saja bisa terjadi di masyarakat, orang tidak akan berkonflik apabila masyarakat itu sendiri tidak menginikan adanya konflik, dalam hal konflik tidak memiliki nilai bilamana masyarakat sudah merasakan adanya kesejahtraan/adil dalam kehidupan berbangsa dan bernegara. Selain itu, konflik bertentangan dengan integrasi sosial. Dimana konflik dan integrasi sosial berjalan sebagai sebuah siklus yang selalu berputar di masyarakat. Konflik yang terkontrol akan menghasilkan integrasi. sebaliknya, integrasi yang tidak sempurna dapat menciptakan konflik.

Louis R. Pondy dalam (Nurchalis, Malik, and Widodo 2017) merumuskan lima tahapan konflik yang disebut "Pondys Model of Organizational Conflict". Menurutnya, konflik berkembang melalui lima fase secara beruntun, yaitu konflik terpendam (laten), konflik terpersepsi, konflik yang terasa, konflik yang termanifestasi, serta konflik sesudah penyelesaian.

Konflik Sosial yang selanjutnya disebut konflik adalah pertentangan atau perseturuan yang terjadi secara fisik dengan adanya kekerasan antara dua kelompok masyarakat atau lebih, yang berlangsung dalam waktu tertentu dan berdampak secara luas bagi masyarakat. Hai ini mengakibatkan ketidak nyamanan dan disintegrasi sosial yang terjadi, sehingga mengganggu kestabilan nasional dan menghambat pertumbuhan pembangunan nasional. Penciptaan ketertiban umum merupakan bagian dari kewenangan yang dimiliki oleh pemerintah dan pemerintah daerah. Konflik terjadi bila ada ketidaksepahaman atau pertentangan atas suatu objek yang sama, ataupun memiliki sasaran-sasaran yang berbeda atas suatu objek itu. Yang terpenting dari suatu konflik adalah ditemukannya keluaran atau solusi atas konflik tersebut. Munculnya konflik sosial di masyarakat tidak akan terjadi dengan sendirinya dan tidak sesederhana yang bisa kita bayangkan bila itu terjadi.

Pada dasarnya konflik merupakan suatu fenomena sosial yang sering muncul dalam kehidupan bermasyarakat. Dalam sejarah bangsa Indonesia saja seringkali diwarnai dengan berbagai konflik, baik konflik yang terjadi antara bangsa Indonesia dengan para penjajah, maupun konflik yang terjadi diantara sesama anak 
bangsa itu sendiri. Misalnya saja konflik yang terjadi pada masa kemerdekaan dan reformasi seperti konflik-konflik sosial terjadi di Ambon, Nangroe Aceh Darussalam, Poso dan di berbagai daerah lainnya di Indonesia.

Fenomena yang berkembang seperti konflik perlu dilihat dari berbagai faktor, seperti dari faktor agama, budaya, sejarah, sosial, ekonomi, politik, dan hukum. Pendekatan multidimensi akan sangat membantu untuk menjelaskan berbagai fenomena sosial yang terjadi di masyarakat.

\section{METODE}

Metode yang digunakan dalam penelitian pendekatan kualitatif deskriptif dengan lokasi penelitian Kota Gorontalo dan Kabupaten Gorontalo. Pada penelitian ini menggunakan studi literatur dengan penelusuran melalui media cetak serta link internet. Data primer dalam penelitian ini melalui interview dengan beberapa informan dan tokoh adat dan budaya, tokoh agama, reskrim Polres Kota Gorontalo.

Setelah data diperoleh, dilakukan pengelompokkan dan dihubungkan antara data yang satu dengan data yang lain untuk memperoleh data yang lebih komprehensif.
Selanjutnya dilakukan analisis data dengan pengelompokan dan membuat urutan data dan selanjutnya dilakukan interpretasi.

\section{HASIL DAN PEMBAHASAN}

\section{Penyebab Konflik}

Sumber konflik menurut (Yadiman and Dahniel 2013) menyebutkan bahwa penyebab terjadinya konflik social antara lain: 1) Perbedaan kepentingan antar kelompok sosial, seperti; perbedaan kepentingan politik, ekonomi, sosial, budaya, agama, 2) Perbedaan pola kebudayaan seperti perbedaan adat istiadat, suku bangsa, agama, paham politik, pandangan hidup, dan budaya darah, 3) Perbedaan antar kelompok sosial, baik secara fisik maupun mental, atau perbedaan kemampuan, pendirian, dan perasaan, 4) Perbedaan kepribadian antar individu, 5) Perubahan-perubahan nilai yang cepat dan mendadak dalam masyarakat.

Hasil penelitian (Mustamin 2016) Konflik terjadi karena pertentangan antar anggota atau antar kelompok dalam masyarakat yang sifatnya menyeluruh, yang di sebabkan oleh adanya beberapa perbedaan diantaranya; Individu, Pola Budaya, Status Sosial, Kepentingan dan Terjadinya perubahan social. 
(Herdiansyah 2018) menyebutkan bahwa perbedaan kepentingan antar actor (pemerintah, masyarakat, dan korporasi) menjadi salah satu penyebab konflik terkait pengelolaan sumber daya alam. Di wilayah perbatasan, konflik muncul karena lahan dan keanekaragaman sumber daya alam yang berpotensi untuk dimanfaatkan tersedia secara melimpah. Dalam pendekatan ekologi politik, perbedaan kepentingan ini dilatarbelakangi oleh motif ekonomi, sosial politik, dan penguasaan lingkungan. Pendekatan ekologi politik dapat membantu menggambarkan fenomena dengan mengaitkan kondisi lingkungan dan proses ekonomi politik.

Konflik dapat berintikan salah satu atau gabungan dua atau lebih diantara inti konflik yang telah disebutkan di atas. Kapasitas masyarakat desa hutan untuk membangun diri sendiri secara terusmenerus, selanjutnya disebutkan bahwa salah satu kebijakan untuk melakukan devolusi yaitu kebijakan pemberian kesempatan bagi masyarakat desa hutan atas hak pengelolaan kawasan hutan negara sesuai karakteristik.

Wirawan (2010) menjelaskan resolusi konflik adalah proses untuk mencapai keluaran konflik dengan metoda resolusi konflik, sedangkan metoda resolusi konflik adalah proses manajemen konflik yang digunakan untuk menghasilkan keluaran konflik yang mencakup metoda pengaturan sendiri (self regulation) maupun metoda intervensi pihak ketiga. Manajemen konflik yaitu praktek mengidentifikasi konflik, menangani konflik secara bijaksana, adil, efisien dan mencegah konflik agar tidak lepas kendali. Metoda pengaturan sendiri yaitu: win-win solution (kolaborasikompromi), win and loses solution (memperkecil posisi lawan), ataupun metoda menghindar, sedangkan metoda intervensi pihak ketiga yaitu melalui pengadilan, proses administrasi, dan resolusi perselisihan alternatif yaitu terdiri dari mediasi, arbitrasi dan ombudsmen.

\section{Pendekatan dan Cara penyelesaian Konflik}

Penyesaian sengketa, pada umumnya terdapat beberapa cara yang dapat dipilih (Harahap 2018) Cara-cara yang dimaksud adalah sebagai berikut ; 1) Negosiasi. Negosiasi yaitu cara untuk mencari penyelesaian masalah melalui diskusi (musyawarah) secara langsung antara pihakpihak yang bersengketa yang hasilnya 
diterima oleh pihak tersebut. 2) Mediasi. Mediasi yaitu upaya penyelesaian sengketa dengan melibatkan pihak ketiga yang netral, yang tidak memiliki kewenangan mengambil keputusan, yang membantu pihak-pihak yang bersengketa mencapai penyelesaian (solusi) yang diterima oleh kedua belah pihak; 1) Pengadilan. Pengadilan adalah lembaga resmi kenegaraan yang diberi kewenangan untuk mengadili, yaitu menerima, memeriksa, dan memutus perkara berdasarkan hukum acara dan ketentuan perundang- undangan yang berlaku. 2) Arbitrase. Arbitrase merupakan cara penyelesaian sengketa di luar pengadilan, berdasarkan pada perjanjian arbitrase yang dibuat oleh para pihak, dan dilakukan oleh arbiter yang dipilih dan diberi kewenangan mengambil keputusan.

\section{Jenis dan Sumber Konflik}

Konflik yang terjadi antara pemerintah dan warga masyarakat dalam penelitian ini bukanlah kondisi yang terjadi sepihak (dominasi/intimidasi/arogansi) pemerintah semata, tetapi juga sebaliknya. Terdapat kondisi dimana rakyat juga melakukan penyerangan terhadap aparat dan perusakan atas sejumlah fasilitas pemerintahan.
Potensi konflik warga dengan pemerintah terjadi dalam ragam kondisi, dimensi serta melibatkan beberapa institusi pemerintah. Isu-isu yang seringkali muncul adalah; 1)Masalah kebijakan pemerintah pusat dan daerah (eksekutuif). 2) Masalah aspirasi rakyat (legislatif daerah). 2) Penegakan hukum/keadilan. 4) Kebijakan pemerintah desa (misalanya pembagian raskin. 5) Pelayanan pendidikan (sekolah)

Potensi konflik pada tahun 2010 hanya sekali terjadi. Hal ini dapat melengkapi asumsi sementara temuan penelitian ini, dimana secara struktur pemerintahan tidak memiliki pemerintahan berbentuk desa (semuanya kelurahan) sehingga tidak ada riak demokrasi tingkat pemerintahan terendah. Konflik politik menonjol selama Tahun 2011 masih terkait dengan perhelatan Pemilu Kepala Daerah.

\section{Potensi Konflik Sumber Daya Alam (SDA)/Ekonomi}

Masalah batas wilayah, Agraria, perebutan lahan, dan sumber daya ekonomi masyarakat adalah bagian yang diekplorasi dalam jenis konflik SDA/Ekonomi. Konflik jenis ini berada pada peringkat kedua dari sisi jumlah (frekuensi) kejadian selama 
Periode Tahun 2010. Konflik ini terjadi sebanyak 12 kali.

$\begin{array}{rcr}\text { Korelasi } & \text { penting } & \text { sejumlah } \\ \text { permasalahan } & \text { SDA/Ekonomi } & \text { cenderung }\end{array}$ berdampak pada konflik lain. Misalnya perselisihan/permasalahan/perebutan lahan pertambangan menimbulkan konflik komunal juga bisa berlanjut dengan konflik pemerintah dan warga masyarakat penambang.

Potensi konflik SDA/ekonomi cukup konsisten dari tahun sebelumnya dengan tahun 2011. Sebelumnya potensi konflik ini berada di urutan kedua dan pada tahun ini juga berada pada peringat yang sama namun degan intensitas kejadian yang mengalami penurunan (dari 43 kejadian menjadi 27). Konsistensi ini menujukkan bahwa masalah pengelolaan SDA/ekonomi menjadi masalah yang terus berulang di tengah masyarakat.

\section{Potensi Konflik Komunal}

Konflik komunal dan konflik-konflik lainnya dapat terjadi tanpa kaitan dengan sejumlah konflik. Namun sebagaimana analisa di atas. Konflik komunal bisa juga merupakan dampak dari satu kejadian konflik, seperti konflik SDA/ekonomi, politik atau juga konflik antar warga dan pemerintah. Secara kuantitatif, jumlah potensi konflik komunal hanya 10 kali terjadi selama Tahun 2010, dengan kualitas rendah. Pengkategorian "rendah" di dasarkan atas dampak yang diakibatkan oleh konflik komunal tersebut tidak melibatkan massa dalam jumlah yang banyak (seperti tragedi poso atau konflik di daerah Madura dan Sampit).

Menarik tentang fakta penelitian yang menemukan bahwa potensi konflik komunal pada tahun 2010 mengalami 8 (delapan) kali. Sebagai pusat Ibu Kota Provinsi dengan perkembangan pembangunan yang menyertainya, menghadirkan sejumlah catatan penting atas potensi konflik masyarakat kota. Potensi konflik komunal berupa tauran antar pelajar, suporter olah raga, kericuhan konser musik dan lain sebagaimnya menjadi bagian dari pemandangan di kota-kota besar pada akhirakhir ini. Dukungan media dan sarana informasi juga menjadi salah satu pemicu perubahan struktur sosial masyarakat.

Catatan sejarah di sejumlah daerah menunjukkan bahwa konflik komunal yang meluas dengan daya destruktif yang kuat berimbas pada konflik yang lebih 
substansial seperti konflik atas nama suku, agama dan ras (SARA). Tingginya jumlah konflik komunal mengindikasikan bahwa daerah-daerah lainnya juga perlu mewaspadai konflik ini. Fenomena dan data tentang perkembangan ekonomi dari tahun ke tahun yang mengalami peningkatan. Peningkatan tersebut juga akan terjadi di daerah-daerah lain, maka dapat dipastikan kemajuan pembangunan daerah akan diikuti pula oleh pergeseran sturuktur ekonomi sosial masyarakat dan peta konflik komunal yang awalnya lebih banyak.

Potensi konflik komunal sangat mendominasi dengan peningkatan yang signifikan dari tahun sebelumnya. Sementara bagi daerah lain yang sebelumnya tidak terjadi potensi konflik komunal, maka pada tahun 2011 terjadi dengan frekuensi yang cukup signifikan pula. Pada Tahun lalu memiliki potensi konflik 10 kasus dan tahun 2011 menjadi 36 kasus.

Salah satu kasus/potensi konflik yang terulang di Tahun 2011 adalah konflik antar oknum di lembaga-lembaga kepolisian dan TNI. Konflik ini terjadi pada satu saat dengan subjek yang berbeda, juga terdapat kasus dimana subjek yang sama namun dengan objek perseleisihan/permasalahan yang sama. Dalam periode potensi konflik tersebut berlangsung, sejumlah mediasi dilakukan, namun hanya menunda konflik lanjutan. Sehingga dengan rentetan kejadian tersebut menambah daftar potensi komunal pada penelitian ini mengalami peningkatan yang signifikan. Demikian pula kriminal/ perkelahian/kekerasan komunal diantara warga masayarakat, suporter dan siswa/ mahasiswa. Tahun sebelumnya potensi konflik komunal ini terjadi dan terulang kembali di tahun 2011. Menariknya tahun sebelumnya tauran antara pemuda kelurahan tidak pernah terjadi, maka pada tahun ini potensi konflik tersebut terjadi.

Seperti dugaan sebelumnya bahwa perkembangan media masa elektornik maupun cetak berdampak pada terbukanya akses informasi yang perlu diwaspadai akses-akses buruk yang menyertainya. Demikian pula perekembangan struktur sosial masyarakat kota yang akhir-akhir ini menujukkan gejala konflik komunal progresif sekaligus kian variatif.

Sejauh pembahasan dan penguraian sejumlah komunal yang dipaparkan dalam penelitian ini, maka dapat dipastikan antara potensi konflik yang satu dengan yang lainnya memliki korelasi dan hubungan baik 
VDL. 6 No. 2 HAL. 145-158

dari riwayat/isu yang melatar belakangi kejadian, pelaku konflik, mupun rangkaian waktu. Misalnya saja masalah/konflik yang berlatar belakang pengusaan Sumber Daya Alam (SDA) atau masalah-masalah politik merembet menjadi konflik laten yang kemudian memicu dendam dan kebencian komunal. Dendam dan kebencian komunal tersebut kian mengalami peningkatan bila mediasi yang dilakukan tidak memadai serta penanganan hukum tidak tuntas.

\section{Potensi Konflik Warga dengan Aparat}

Potensi konflik warga dengan aparat terjadi sekitar $35,82 \%$ kasus konflik, sejatinya pemerintah sebagai pelayan masyarakat sedapat mungkin melaksanakan fungsi utamanya tersebut agar warga masyarakat merasa memiliki pemerintahannya dan terjalin hubungan yang harmonis antara keduanya. Namun dapat dimaklumi bahwa setiap kebijakan atau tindakan apapun oleh pemerintah biasanya menimbulkan pro dan kontra ditengah masyarakat. Pro dan kontra tersebut merupakan kewajaran. Namun menjadi sesuatu yang lain bila perbedaan tersebut menimbulkan konflik yang tidak dapat ditolelir. Salah satu contoh riil yang sering terjadi adalah, di satu sisi pemerintah hendak melakukan fungsi untuk penertiban. Di sisi yang lain masyarakat yang terkena dampak melakukan resistensi (perlawanan) atas kebijakan tersebut. Kondisi ini menuntut komunikasi yang baik antara kedua belah pihak agar konflik dapat dihindari. "mengorbankan kepentingan minoritas untuk kepetingan umum" hendaknya dihindari agar negara tidak berjalan dalam imajinasi kekuasaan semata. Tindakan represif terhadap warga bukanlah solusi, karena dengan tindakan-tindakan semacam ini justeru akan menimbulkan konflik laten yang sewaktu-waktu dapat dipicu lagi oleh kebijakan-kebijakan pemerintah berikutnya.

Sebagai potensi konflik yang paling dominan di antara potensi konflik-konflik lainnya, salah satu solusi penting untuk masalah ini adalah dengan membuka ruang partisipasi masyarakat dalam pengambilan keputusan publik. Sebagai salah satu prinsip good governance, partisipasi masyarakat bukan sekedar simbol tetapi benar-benar terimplementasi pada seluruh rangkaian kebijakan pemerintahan dan pembangunan. Pemerintah dapat melakukan uji publik terlebih dahulu sebelum mengeluarkan/ mengambil tindakan untuk memperoleh 
respon/ tanggapan publik. Atas tanggapan tersebut pemerintah membuka komunikasi yang intens sekaligus sosialisasi yang memadai agar terjadi kesamaan paham dalam setiap kebijakan.

Potensi konflik antara warga dan aparat pemerintah tahun 2010 sebanyak 67 kasus/kejadian/potensi dan pada Tahun 2011 mengalami penurunan yang sangat signifikan menjadi 23 kasus/kejadian. Walaupun angka tersebut mengalami penurunan, namun merujuk pada substansi dan filosofi eksistensi pemerintahan sebagai pelayan masyarakat maka seharusnya potensi/potensi semacam ini tidak terjadi. Potensi konflik warga dan aparat pemerintah sering terjadi.

Potensi Konflik Suku, Agama dan Ras (SARA)

Isu dan konflik Sara yang terjadi di Indonesia pada beberapa tahun terakhir ini menjadi perhatian tersendiri bagi pemerintah pusat sampai dengan pemerintah daerah. Berbagi forum difasilitas oleh pemerintah untuk meminimalisir terjadinya konflik Sara. Forum Kewapadaan Dini Masyarakat (FKDM), Forum Kerukunan Antar Umat Beragama (FKUB). Forum Pembauran
Kebangsaan dan lain sebagainya adalah bagian dari upaya-upaya tersebut.

Menarik, bahwa rentetan kejadian konflik dengan unsur Sara di Indonesia tidak diikuti oleh masyarakat Kota Gorontalo. Perbedaan keyakinan, keragaman suku dan budaya serta perbedaan ras tidak menjadi pemicu konflik. Hal ini bisa dipengaruhi oleh tiga hal peting sebagai karakaterisitik masyarakat Gorontalo; 1) Secara kuantitas mayoritas penduduk masyarakat beragama Islam sehingga jarang timbul perbedaan keyakinan. 2) Keberhasilan pemerintah membuat forum-forum yang mempertemukan perbedaan Sara. 3) Budaya masyarakat yang ramah dan toleran terhadap perbedaan. 4) Proses pembauran berjalan dalam ritem budaya lokal.

Selama Tahun 2010 hanya sekali terjadi potensi konflik yang berlatar belakang agama. Namun hal ini terjadi pada saat Forum Musyawarah Pondok Pesantren Putri (FMP3) mengeluarkan fatwa haram rebonding (rekayasa meluruskan rambut), hal ini menjadikan pekerja Rebonding merasa garang dan meminta agar di kaji lebih mendalam karena sebab usaha reebonding sudah menjadi mata pencaharian utama masyarakat di Kota Selatan Kelurahan 
Tenda. Tahun lalu potensi konflik yang berakar dari unsur SARA hanya sekali terjadi. Tahun 2011 telah terjadi peningkatan dari sisi jumlah yang mencapai 7 potensi konflik dengan 4 kejadian.

Potensi koflik Sara yang terjadi di tahun 2011 diakibatkan oleh beberapa hal, diantaranya adalah penolakan masyarakat atas keberadaan Ahmadiyah dan Tarekatul Ma'rifatullah Al-Qodiriyyah. Potensi konflik Sara lain terjadi antara pemerintah dengan warga masyarakat. Misalnya, terjadi pembubaran kegiatan peringatan hari besar Islam oleh pemerintah.

\section{Potensi Konflik Hubungan Industrial dan}

\section{Buruh}

Potensi Konflik Hubungan Industrial dan Buruh terjadi di tahun 2010 sebanyak 3 kali. Namun di tahun 2011 tidak terjadi konflik hubungan Industri dan Buruh.

Sebagai sebuah kota Provinsi, sebagaian besar penduduknya bekerja disektor jasa, industri dan perdagangan dan juga merupakan kota pendidikan untuk wilayah Provinsi Gorontalo. Sebagai pusat jasa pemerintahan dan swasta serta pusat pendidikan serta perdagangan dan Industri, telah menempatkan Kota Gorontalo menjadi daerah dengan tingkat heterogenitas yang cukup tinggi bila dibandingkan dengan daerah lainnya yang ada di Provinsi Gorontalo.

Dari enam jenis konflik yang dieksplorasi dalam penelitian ini, ternyata jenis konflik antara warga masyarakat dengan pemerintah sangat dominan terjadi dengan prosentasi mencapai 50\%. Berikutnya adalah potensi konflik SDA/ Ekonomi dengan prosentasi $26 \%$, potensi konflik komunal sebesar 18\%, sedangkan untuk potensi konflik politik, Sara dan hubungan industri, masing-masing hanya sebesar $2 \%$ saja.

Grafik I. Potensi Konflik Tahun 2010

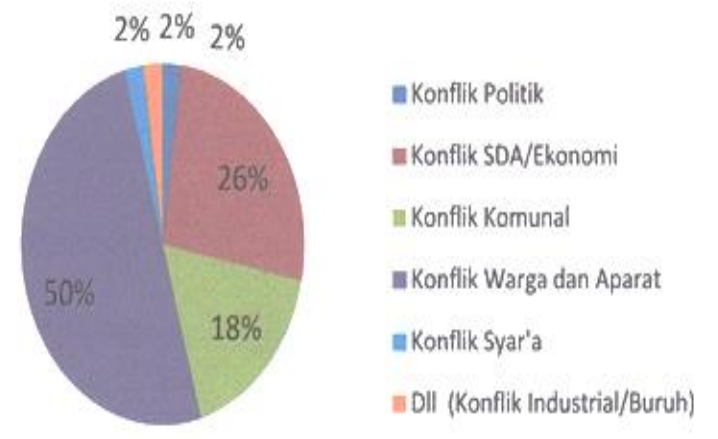

Sumber: Data Lapangan diolah, 2013

Potensi konflik antara warga masyarakat dengan pemerintah lebih banyak dipicu oleh upaya penertiban yang dilakukan oleh Satuan Polisi Pamong Paraja 
(Satpol PP) terhadap pasar, tempat hiburan, pelebaran jalan, eksekusi rumah. Sementara konflik komunal yang lebih banyak terjadi sepanjang tahun 2010 adalah pertikaian antar warga juga tauran antar pelajar.

Pada tahun 2011 potensi konflik paling banyak dikontribusi oleh jenis konflik komunal mencapai $57 \%$, selanjutnya potensi konflik politik sebesar $22 \%$, potensi konflik antar warga dan aparat sebesar $10 \%$ dan sisanya potensi konflik Sara dan konflik SDA/ekonomi masing-masing sebesar $6 \%$ dan $5 \%$.

Terjadi pergeseran dominasi potensi konflik dari tahun 2010 ke tahun 2011. Dimana pada tahun sebelumnya dominasi potensi konflik tersebut adalah konflik antar warga dan aparat pemerintah, namun tahun ini yang lebih dominan adalah potensi konflik komunal. Tak banyak informasi yang dapat menjelaskan meningkatnya potensi konflik komunal terjadi, tetapi bila merujuk pada sejumlah data yang berhasil teridentifikasi dari penelitian ini, maka hal terseburt diduga kuat akibat meningkatnya perselisihan/pertikaian/permasalahan yang terjadi antara oknum insitusi penegak keamanan ketertiban masyarakat (TNI dan Polri) pada periode 2011. Masalah kalisik lainnya dalah pertikaian antar warga dan atau suporter pendukung olah raga, dan tauran antar siswa.

Grafik II. Jenis Potensi Konflik Tahun 2011

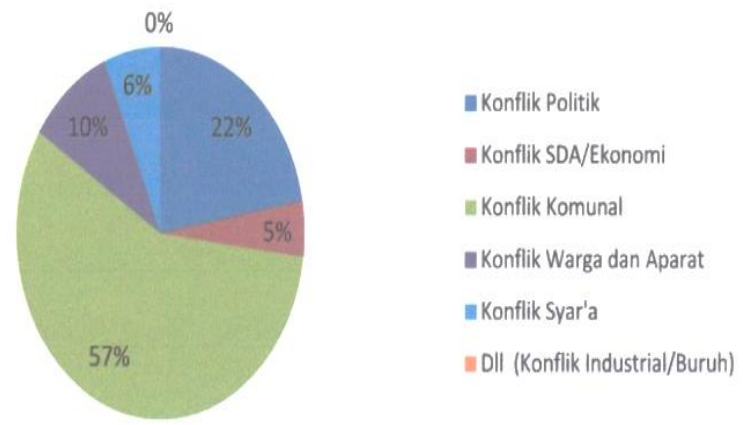

Sumber: Media Monitoring RCM IAIN Gorontalo \& Data Lapangan, 2013

Potensi konflik berikutnya yang cukup signifikan peningkatannya terjadi adalah konflik unsur agama (sara), yang tahun sebelumnya hanya sekali terjadi, namun tahun 2011 mencapai 4 kali kejadian. Isu potensi konflik Sara lebih banyak berkaitan dengan penolakan atas sejumlah paham/ aliran sesat (seperti Ahmadiyah).

\section{SIMPULAN}

Berdasarkan hasil pengumpulan data lapangan serta penelusuran terhadap berbagai dokumen media baik elektronik (online) mapun cetak diperoleh beberapa kesimpulan penting terkait potensi, pemetaan jenis \& sumber konflik, yaitu : 1) Jenis konflik dapat di kategorikan menjadi enam jenis konflik 
yakni ; (a) Konflik politik (Pilkada), (b) konflik pengelolaan Sumber Daya Alam, Agraria dan perebutan sumber-sumber ekonomi, (c) konflik komunal warga ; suku, Ras antar Golongan, (d) konflik warga versus aparatur baik Sipil maupun pihak kemanan, (e) Konflik sara, sektarian, agama dan (f) konflik industrial (buruh). 2) Konflik berdasarkan data tiga tahun terakhir (20102012), menunjukan kecenderungan pola dan potensi pergerakan konflik yang relative sama. Konflik pengelolaan SDA dan Agraria sebagian besar Sumber Konflik berasal dari tuntutan hak pengelolaan yang tumpang tindih. Untuk konflik Agraria dominan bersumber dari perlawanan oleh pihak yang tergugat atas eksekusi tanah. 3) Jenis konflik antara warga dengan aparat pemerintah mendominasi jenis konflik yang terjadi. Konflik antar warga dengan aparat pemerintah yang tinggi. Dari tahun 2010 sampai dengan Tahun 2011 sering terjadi konflik. Konflik yang dominan terjadi di sebabkan oleh antara satu konflik dengan konflik yang lain dapat terjadi secara simultan dan saling mempengaruhi. 4) Konflik sara, sektarian, agama dan konflik industrial (buruh) merupakan jenis konflik yang minim terjadi, namun potensi konflik ini sangat terbuka di masyarakat yang semakin heterogen.

\section{DAFTAR PUSTAKA}

Agus Sjafari. 2017. "Pemetaan Konflik Sosial Di Kota Tangerang Provinsi Banten." Goverment - JOG 2(3): 13557.

Harahap, Suheri. 2018. "Konflik Etnis Dan Agama Di Indonesia." Jurnal Ilmiah Sosiologi Agama (Jisa) 1(2): 1.

Herdiansyah, Herdis. 2018. "Pengelolaan Konflik Sumber Daya Alam Terbarukan Di Perbatasan Dalam Pendekatan Ekologi Politik." Jurnal Hubungan Internasional 7(2): 143-51.

Mustamin. 2016. "Studi Konflik Sosial Di Desa Bugis Dan Parangina Kecamatan Sape Kabupaten Bima Tahun 2014." Jurnal Ilmiah Mandala Education 2(2): 185-205.

http://ejournal.mandalanursa.org/index. php/JIME/article/view/109.

Nurchalis, Andi, Ichsan Malik, and Pujo Widodo. 2017. "Resolusi Konflik Batas Wilayah Kabupaten Gorontalo Kabupaten Gorontalo Utara (Studi One Map Policy) Borderline Conflict 
Resolution in Gororontalo Regency North Gorontalo Regency (One Map Policy Study)." Prodi Damai dan Resolusi Konflik 3(3): 17-38.

Wirawan. 2010. Konflik dan Manajemen Konflik: Teori. Aplikasi, dan Penelitian. Jakarta: Salemba Humanika

Yadiman, H., and Rycko Amelza Dahniel. 2013. "Konflik Sosial Dan Anarkisme." Andi Offset, Yogyakarta.

\section{PROFIL SINGKAT}

Hasanuddin menamatkan pendidikan sarjana pada Jurusan Akuntansi STIEM Bongaya Makassar tahun 2003, kemudian melanjutkan pendidikan Magister Sains Pada Jurusan Manajemen dan Keuangan UNHAS tahun 2007 dan selesai tahun 2009. Pada periode 2017 sampai dengan 2020, melanjutkan pendidikan doktor di Universitas Muslim Indonesia Makassar, pada Jurusan Ilmu Manajemen. Saat ini aktif sebagai tenaga pengajar (Dosen) Pada Fakultas Ekonomi, Program Studi Manajemen, Universitas Gorontalo. 